\title{
OTHOLOMICS
}

Revista d'economia, empresa i societat

Dossier on collaborative economy (I)

Platform economies and collaborative business

Coordinator: Joan Torrent-Sellens

REVIEW OF THE CONCEPTUAL FRAMEWORK

\section{Collaborative consumption, a buzzword that has gone conceptual: Three shades of the sharing economy}

\section{Myriam Frtz}

LaboNFC (Laboratory of Research on New Forms of Consumption)

Université du Québec à Chicoutimi

\begin{abstract}
It has been a decade now that research on the collaborative economy and collaborative consumption (CC) has thrived. Tremendous academic research has been conducted into this specific concept. This paper re-evaluates the conceptual framework proposed almost half a decade ago about the conceptual foundations, frontiers and limits of the concept of collaborative consumption. The paper provides a revised definition and assesses to what extent the scope and limits in contrast to other forms of exchange still hold now despite current challenges.
\end{abstract}

KEYWORDS collaborative consumption, collaborative economy, sharing economy, conceptualization, conceptual framework, exchange

REVISIÓ DEL MARC CONCEPTUAL

El consum col/laboratiu: de paraula de moda a terme conceptual. Les tres cares de l'economia compartida

RESUM Des de fa una dècada, les recerques relatives a l'economia colllaborativa i el consum col/laboratiu (CC) han anat en augment. Les recerques més importants realitzades s'han centrat en aquest concepte en particular. Aquest article busca reconsiderar el marc conceptual del consum col/laboratiu després de gairebé un lustre d'haver estat formulats els conceptes que van establir els seus fonaments, termes i límits. Per a això, ofereix una definició revisada i una avaluació de l'àmbit $i$ els límits del concepte. Mitjançant la comparació amb altres formes d'intercanvi, explora si aquest continua vigent malgrat els reptes que avui es presenten.

PARAULES CLAU consum colllaboratiu, economia colllaborativa, economia compartida, conceptualització, marc conceptual, intercanvi 


\section{Introduction}

Early on, we identified consumers' capacity to switch side from "obtainment" to "provision" or from an "obtainer" to a "provider" role as the key criterion of collaborativity, hence of the collaborative economy (CE) (Ertz et al., 2016). At that time this was much in line with other seminal works such as Botsman and Rogers (2010) and Gansky (2010), while differing slightly from those works by adopting a scholarly perspective (vs. a managerial one) and framing consumers' ability to switch roles from obtainer to provider as the key defining criterion of collaborative consumption (CC). As such, CC can be defined as a set of resource circulation systems which enable consumers to both obtain and provide, temporarily or permanently, valuable resources or services through direct interaction with other consumers or through a mediator (Ertz et al., 2019). Collaborative consumption is therefore a concept which stands in sharp contrast with the notion of conventional consumption. Conventional consumption - which underlies classic marketing thought - is a type of resource distribution system which involves passive consumers (not obtainers), who cannot, or are not given the capacity to, provide any resource or service (not providers). Incapable of engaging either in obtainment or in provision, their role is limited to that of buying - monetary exchange - and consuming organization-made resources or services, and, in the case of tangible resources, to discard them. In contrast, collaborative consumption involves not mere "consumers" but "obtainers" who may also be "providers". In sum, consumers' capacity to switch roles from provider to obtainer and from obtainer to provider in a given resource distribution system constitutes the key distinguishing criterion between conventional consumption and CC.

With regards to the scope and limits of the collaborative consumption, our stance was that it is comprised of two major blocks (Ertz et al., 2017): namely what we call 1) "mutualization" (i.e., renting, leasing, pooling, sharing [Gaiardelli et al., 2014]), in line with Arnould and Rose's (2016) call for integrating the mutuality construct as a substitute for the vaguer "sharing" notion; and 2) "redistribution" which involves the reownership of resources through giftgiving (or donations, passing along, giving tax deductions), swapping and secondhand markets. The rationale being that since our CC-defining criterion is ability to enact the obtainer-provider switchover, reownership markets enable that switchover. This article takes a broader perspective on the matter by conceptualizing the collaborative economy and the sharing economy.

\section{Toward a new conceptualization of collaborativity and the collaborative economy}

\subsection{The definitional conundrum issue}

One recurrent feature of research in the CE and CC is the declaration that there is a "definitional conundrum" about the CE and CC (Murillo et al., 2017). Some authors do not attempt to define the CE (Plewnia and Guenther, 2018). Other authors tend to use inconsistent definitions throughout their work (e.g., Muñoz and Cohen, 2018). In their study of sharing economy business models, Curtis and Mont (2020) concluded nonetheless that there is a need to use a coherent definition throughout a specific work about the CE and to better "demarcate those practices included or excluded in the authors' definition of the sharing economy" (p. 4). We note however that the CE concept has increasingly been narrowed to one of its specific subcomponents that especially deals with webmediated mutualization practices.

Such conceptualization is becoming increasingly common and prevalent, probably because platforms and applications enabling consumer co-production constitute highly innovative and fast-growing segments of the overall CE. For example, Dellaert's (2019) developed a two-layered conceptual framework of consumer co-production networks in the CE. Given the mesh-like and rhizomatic features of the Internet (Giesler, 2006), web-powered networks were highly prevalent across all four categories of co-production networks. Given the increasingly prevalent dominance of 
platforms in the CE, many authors have gradually moved to the notions of "gig economy" or "platform economy", which are governed by "sharing platforms" to describe entities that facilitate "sharing practice" (Akbar and Tracogna, 2018; Ciulli and Kolk, 2019; Piscicelli et al., 2018; Hawlitschek et al., 2018). That web-centric focus has created a whole new subfield of research in the broader sharing economy area to the point that "sharing economy" and "platform economy" are often being conflated. In Ertz and Leblanc-Proulx's (2018) co-citation analysis of the collaborative economy, this subfield of research refers to cluster 3, which focuses on mutualization and sharing systems of all types of resources from a technological (platform) perspective. For example, Eckhardt et al. (2019) define the sharing economy as a technologically enabled socioeconomic system with key impacts on traditional beliefs and practices in marketing. Likewise, Curtis and Mont (2020) narrow the "sharing economy" to the "sharing platform" concept. Such platforms are considered as business models that create value by the mediation of an exchange between a provider called "resources owner" and an obtainer called the "resource user" (Curtis and Mont, 2020). These are just a few examples among many others that have adopted a tech-oriented perspective on the sharing economy.

\subsection{The definitional conundrum issue}

Concepts change and evolve. We may move from consumers to co-producers, from providers to resource owners (Curtis and Mont, 2020) or service providers (Andreassen et al., 2018; Benoit et al., 2017) and from obtainers to resources users (Curtis and Mont, 2020) or consumers (Andreassen et al., 2018; Benoit et al., 2017). Yet, that evolving loghorrea appears to refer consistently to the same fundamental principle of the collaborative economy. That is, consumer-to-consumer or peer-to-peer exchange that may be mediated by some kind of "middleman" whether it is a platform, an application or any other business model that creates value through facilitating the matching between provision and obtainment. This conceptualization matches closely the one we developed in 2016 and prolonged in 2019. Curtis and Mont (2020) further suggest that this switchover feature is actually a key condition for improved sustainability performance in the CE. They state:

"We suggest SEBMs for sustainability operate as a platform that leverages technology to facilitate a twosided market between a resource owner and resource user. As such, this condition excludes businessto-consumer models that do not operate a two-sided market." (p. 6).

They nonetheless include business-to-peer models that operate as "two-sided markets", also called triadic business models that facilitate (rather than create) value as an outcome of the interaction between the supply and the demand side of an exchange system (Andreassen et al., 2018; Rysman, 2009). The authors mention "Spacious", a co-working platform outfit that offers space in restaurants during the day as an example of a two-sided market that can thus be considered to be part of the sharing economy.

Yet, two-sidedness should not be the exclusive criterion to assess whether a business is collaborative or not. This discussion goes obviously beyond the authors' original purpose since they merely aimed at improving sustainability in collaborative business models. However, what Spacious and other co-working platforms basically offer is to occupy otherwise vacant commercial spaces (e.g., restaurants only open for dinner, retailers closed on specific hours) to create cost-effective working units that generate additional income for landlords (Brown, 2020). If we refer to our original conceptual framework of the CE, Spacious is ambivalent since it may or may not constitute a form of CC depending on its configuration. More specifically:

1) If the platform enables a consumer to lend space to another consumer (C2C) or even a company (C2B), the platform conforms to the defining criterion of collaborativity (Ertz et al., 2016, 2019) by being a resource circulation system that enables consumers to switch roles from obtainers to providers.

2) If the platform allows solely private companies to lend space to consumers or businesses, the configuration is $\mathrm{B} 2 \mathrm{C}$ and $\mathrm{B} 2 \mathrm{~B}$ respectively, and aligns with conventional consumption.

Since Spacious like many other sharing platforms allow both, they are intermittently collaborative. In other words, they enable conventional exchange configurations by allowing companies to provide resources to users (B2C) or companies (B2B). Yet, since those platforms also enable consumers to switch over (from user to provi- 
der), they may simultaneously be deemed collaborative. The same holds for other giants of the sharing economy including Uber, Airbnb, Instacart and so on. Meelen and Frenken (2015) drew the distinction between peer and professional providers. Non-professional or peer providers supply resources that they personally own such as their own home, space, car, tools, or skills to others. In contrast, professional providers supply resources that belong to the commercial entity that they represent. As a concrete manifestation of that tension between collaborativity involving peer supply and non-collaborative configurations referring to professional supply, Gyódi (2019) revealed that only a small minority of Airbnb listings can be classified as what he calls "sharing economy services", in the sense of peer hosting (thus involving collaborativity), while commercial offers, in the sense of professional hosting, constitute a significant share of listings on the platform:

"The offers that represent sharing economy services constituted a minority of the offers in all of the analysed cities. Our results confirm the assumption that a significant share of Airbnb offers are listed by professional businesses, and may therefore contribute to gentrification" (p. 537).

It is therefore more accurate to frame what the literature has come to monolithically call the "sharing economy" as a general umbrella term (Hamari et al., 2015; Dreyer et al., 2017; Guyader and Piscicelli, 2019), which comprises three forms of exchange with varying degrees of collaborativity as shown in Table 1.

Table 1. The sharing economy and collaborativity

\begin{tabular}{|l|l|l|}
\multicolumn{1}{|c|}{ Pure collaboration } & Intermittent collaboration & Pseudo collaboration \\
\hline Direct collaboration & Pure collaboration & Conventional consumption \\
\hline Facilitated collaboration & Conventional consumption & \\
\hline Mediated collaboration & & \\
\hline
\end{tabular}

Source: Own elaboration.

The remainder of this article will describe each of those three prototypical forms of collaborativity in more details. Importantly, while our work has progressed since our earlier definition of collaborativity, we maintain that the sharing economy in general, and the collaborative economy, in particular, may still be deployed across both purely online or offline channels as well as in a multichannel perspective; while involving diverse forms of compensation including but without being limited to money. This includes therefore flea markets, swapping meets, garage sales, secondhand stores, donation centers, trade-in schemes, and many other similar collaborativity-fuelled exchange schemes.

\section{The three shades of collaborativity}

\subsection{Pure collaboration}

The notion of "pure collaboration" remains partially unchanged since our initial categorization (Ertz et al., 2016, 2019). First, it still refers to direct peer-to-peer (or consum-er-to-consumer) exchanges in which consumers directly exchange resources with each other or access to each other's resources. This we call "direct collaboration". However, in contrast to our past conceptualization in which we stressed that purity occurs "without any intermediary, whether facilitator or mediator" (p. 30) (e.g., garage sales, swap meets, flea markets), we stress that intermediation may in fact occur and is increasingly occurring to facilitate exchanges and make them more efficient (Curtis and Lehner, 2019; Curtis and Mont, 2020). Consequently, the two forms of "facilitated collaboration" and 
"mediated collaboration", that we framed in addition to pure collaboration, could actually conflate with pure collaboration. Pure collaboration thus entails by order of collaborativity, direct collaboration, facilitated collaboration and mediated collaboration. The latter two are described in more details as follows:

- Facilitated collaboration involves P2P exchanges that are facilitated by an intermediary. For example, "the Canadian-based platform TheCarpoolingNetwork.ca enables consumers who wish to obtain a ride to connect with consumers who are willing to offer a ride, and to arrange between themselves the terms and conditions related to that ride, with the website acting merely as a facilitator" (Ertz et al., 2019, p. 30).

- Mediated collaboration involves exchanges in which organizations not only facilitate but create the value creation process, thus acting as mediators. The mediation process occurs in two steps.

First, through sourcing collaboration, the mediator relies on consumers who provide a resource or service (Ertz et al., 2019). For example, a telecommunication provider may act as a mediator sourcing collaboration when a consumer trades in a used mobile phone.

Second, through trading collaboration, the mediator redistributes the resource or service to would-be obtainers, usually by adding some value such as reconditioning, terms and conditions which increase service quality, and so on (Ertz et al., 2019). In our previous example, the telecommunication provider adds value by refurbishing the mobile phone before reselling it to consumers (i.e., obtainers).

The frontier between facilitated and mediated collaboration may often be thin and merge especially in an online context where platforms tend to do much more than merely facilitating exchange between providers and obtainers. For example, Uber not only acts as a matching platform but imposes also a broad range of terms and conditions to its drivers regarding the type of car being used, the offering of water bottles and sweets, or even the behavior etiquette, and the pricing scheme with its surge pricing algorithm, all in an attempt to improve service quality and thus contribute to the value creation process.

Besides, finding an organization or platform working solely on the principle of pure collaboration is challenging especially in an online context where intermittent collaboration tends to prevail.

\subsection{Intermittent collaboration}

Intermittent collaboration refers to resource circulation systems which combine both pure collaboration and conventional consumption. The notion of conventional consumption might be unsettling here but it relies fundamentally on the modernist distinction between the production/distribution world and the consumption one. More concretely, that divide refers to conventional commercial exchanges involving organizations selling to consumers (B2C) or inter-organizational commerce (B2B). Initially, we excluded this second form of our conceptionalization of CC as it is antithetical to collaborativity (Ertz et al., 2016). From an essentialist perspective, the divide implied by modernism renders the possibility of switchover, that characterizes collaborativity, impossible. We maintain that collaborativity refers to the switch. Meanwhile, intermittent collaborativity blends in with the recent advances that have been made in marketing, consumer behavior, and management drawing on anthropological and sociological literature, acknowledging the hybrid or dual essence of the economy. In sum, the format / modernist perspective that makes that clear distinction between the production work and the consumption world (i.e., conventional consumption) is inevitably coupled with a postmodernist perspective in which these distinctions blur, allowing for an intertwining of the classic exchange paradigms of gift-giving, barter and commodity exchange, rather than a strict distinction between those (Scaraboto, 2015; Corciolani and Dalli, 2014; Dalli and Corciolani, 2008; Perren and Kozinets, 2018). Any entity (consumer or organization) has inherently a "deficit" (demand) and a "surplus" (supply) side which constantly interact in the form of active exchange of resources (Breyer, 1934; Shaw, 2014; Ertz and Sarigöllü, 2019). A company's surplus side thus fulfills a consumer's deficit side, while that same consumer's own surplus side may fulfill another consumer's or organization's deficit side through a breadth of exchange configurations including gift-giving, reselling, swapping, and so on (Ertz and Sarigöllü, 2019).

Intermittent collaboration reconciles therefore the consumer-business and commercial-disinterested tensions that have been observed in the sharing economy (Slee, 2015; Morozov, 2013; Murillo, Buckland and Val, 2017) 
by acknowledging that an intermingling of exchange configurations (i.e., C2C, C2B, B2C, B2B) as well as compensations forms (i.e., without compensation, with money compensation, with other compensations) might occur and actually constitutes the most accurate conceptual mirroring of praxis.

It should however be stressed that intermittent collaboration necessitates the allowing for collaborativity, in the sense of consumers switching over roles from users to providers. Spacious, Uber, Airbnb, Boatsetter, Peerby, Craigslist, indeed allow for consumers to become providers while simultaneously providing space for conventional companies, be they hotels, professional drivers, car lenders, boat lenders, retailers or manufacturers, to do exactly the same. Yet, in many cases the switchover is denied and this leads us to the third and last component of the sharing economy, pseudo collaboration.

\subsection{Pseudo collaboration}

Pseudo collaboration refers to resource circulation systems that do not enable (at all) consumers switching over from their current consumer role to that of a provider. As such, it incarnates the modernist exchange paradigm in its purest form. Many organizations that entered the market at the beginning of the sharing economy boom such as carsharing businesses Car2Go or Zipcar, but also bike-sharing Mobike, Ofo, OBike, or Lime, have been wrongly framed as part of the "sharing economy", while in fact denying consumers to switch over. Seminal authors Botsman, Rogers or Gansky and others classified such organizations as collaborative on the basis that they allow short-term rentals and could thus be equated with "sharing" and "collaborative" business models. Yet, how would such businesses then compare to conventional car lenders such as Avis or Enterprise? The same can be said for bike-sharing service providers. That misclassification has been abundantly discussed in the literature (Slee, 2015; Schor, 2016; Ertz and Leblanc-Proulx, 2018; Frenken and Schor, 2019) and reiterating what has already been said is purposeless and goes beyond the scope of this paper. Other authors in the likes of Bardhi and Eckhardt (2012) adopted a more nuanced position by framing such exchange schemes as "access-based consumption". Lamberton and Rose (2012) called them "marketing-managed sharing systems". These are all more appropriate characterizations of those organizations. This paper takes a broader orientation by using the concept of "pseudo collaboration".

Importantly, pseudo collaboration should not be confounded with pseudo sharing. According to Belk (2014), pseudo-sharing refers to commodity exchange wrapped in the more acceptable and appealing terminology of sharing. More specifically, business transactions involving money flows are masqueraded as forms of communal sharing (Belk, 2014; Eckhardt and Bardhi, 2015). Likewise, Martin (2016) denounced the framing of the sharing economy as an economic innovation and a pathway to more sustainability in consumption while actually creating highly unregulated marketplaces. Morozov (2013) talked of neoliberalism under steroids. That disguise of the neoliberal wolf in the altruistic sheep's clothes is pseudo sharing but it differs from pseudo collaboration. In fact, the pseudo sharing construct is especially disturbing for scholars framing the CE as being essentially about sharingrelated practices such as lending, leasing, pooling and obviously sharing, which we summarize under the broader mutualization concept. Table 2 explains the differences between these different mutualization concepts.

\section{Table 2. Sharing-related concepts}

\begin{tabular}{|l|l|}
\hline \multicolumn{1}{|c|}{ Mutualization schemes } & \multicolumn{1}{c|}{ Definitions } \\
\hline Leasing & The lessee pays a regular fee for unlimited and individual use of the product \\
\hline Renting & The customer uses the product individually for a predetermined period \\
\hline Sharing & The product is sequentially used by different customers \\
\hline Pooling & The simultaneous use of a product by different customers \\
\hline
\end{tabular}

Source: Adapted from Ertz, Leblanc-Proulx, Sarigöllü, and Morin (2019, p. 872). 
Yet, our original conceptualization of CC placed mutualization and redistribution as being both key components of the CE (Ertz et al., 2019, p. 33). Besides, exchange can be free through donations (Giesler, 2006), charity donation (Bergadaà, 2006), legacies and bequests (Curasi et al., 2004); for points of other currency such as on Barterquest (Botsman and Rogers, 2010), and trade in programs (vouchers, credits) (Eisend, 2015); for other items through swapping with swap meets (Belk et al., 1988) or local exchange trading schemes, time banks, and community currencies (Seyfang and Longhurst, 2013); subscription-based such as in tool libraries (Lamberton and Rose, 2012); or at a cost such as in secondhand marketplaces (Guiot and Roux, 2010), including auction websites (Chu and Liao, 2007) or private sales by the government.

Because we do not take a restricted approach focused on the sharing notion with all the semantic connotations that come inherently with it, our conceptualization is not hindered by pseudo sharing issues. It might however be surprising to consider pseudo collaboration as part of the sharing economy. This is because several papers including seminal ones conflated such types of exchange (see above for references) with the sharing economy (e.g., Hamari et al., 2015). Therefore, as an attempt to circumscribe the current literature, we posit impure collaboration in the form of pseudo collaboration as a third layer of the sharing economy. Yet, that layer does not overlap with the collaborative economy which remains distinct. As shown in Figure 1, the collaborative economy encompasses pure collaboration, obviously, but also that facet of intermittent collaboration which entails pure forms of collaboration. The sharing economy concept, in contrast, subsumes the three components of pure collaboration, intermittent collaboration and pseudo collaboration.

Figure 1. The inter-linkages between the collaborative economy, the sharing economy, and the three shades of the sharing economy



Source: Own elaboration.

\section{Perspectives for the future}

What has come to be known as sharing platforms relies on a triadic perspective which involves three actors (Hawlitschek et al., 2018): 
- Suppliers: these may be hosts on Airbnb, drivers on Uber or car owners on Turo. They offer a specific resource, that is generally underutilized or unused;

- Users: these may be the guests on Airbnb or the passengers on Uber. They seek to access either temporarily or permanently the proposed resource through various means.

- Collaborative platforms: they act as an infrastructure for the mutualization or redistribution of resources between obtainers, as well as the maintenance of trust for the realization of exchanges.

Yet, that triadic equilibrium could be threatened in the future with profound implications for collaborativity and the collaborative economy. These shifts could in fact reshape our views on the future of the collaborative economy and the broader sharing economy.

\subsection{The disappearing peer provider?}

The most crucial aspect in this regard deals with the diminishing role of peers as providers. While Gyódi (2019) already emphasized that peer providers are marginal in comparison with business providers, at least on Airbnb, these findings signal potentially an underlying trend towards the expelling of the peer as a provider. Technology, which contributed to empower individuals through peer-to-peer exchange, could backlash. With the rapid development of technological innovation, an increasing number of platforms seek to replace providers, be they peers or businesses, by machines. The most telling example in this regard refers to Uber's recent attempts to develop selfdriving systems which include sensors that may view 360 degrees around the car (Uber ATG, 2020). Automation could further impact a host of jobs that burst with the emergence of platforms. For example, the delivery men of restaurant food delivery services and more broadly the Q-commerce (Lange, 2020) such Uber Eats, Foodora, or Deliveroo, but also Postmates and Instacart could well be replaced by cheaper robots or drones, and of course, self-driving cars and trucks. Q-commerce is the abbreviation of "quick commerce" which is being considered as the next generation of e-commerce. It draws on the platform economy business model to bring small quantities of goods to customers almost instantly (Lange, 2020). What value could then peer providers put forth to compete with machines that can work 24/7 at a fraction of their own price? The peer providers may therefore survive in niche markets where relationality in the form of human contact remains essential such as teaching, coaching or training for example. They may also survive in the provision of higher-end premium services. Machines will essentially deliver cheaper services while having the opportunity to deal with a human will be highly priced. It is also worth mentioning that the receding of peer providers will inevitably dampen pure collaboration and the collaborative economy while contributing to the incessant growth of intermittent collaboration and pseudo collaboration.

\subsection{The disappearing platform?}

With all these developments it might seem limpid that platforms will thrive at the expense of peer providers. Yet, nothing is more certain either. As an inherently connected economy, the sharing economy and collaborative economy is prone to integrate the most recent technological advances such as artificial intelligence, the smart grid, big data analysis, augmented reality, as well as blockchain technology. While most of these technologies will essentially contribute to render providers less useful, the blockchain technology might actually make the platform itself redundant (Ertz and Boily, 2019). In fact, the blockchain is a decentralized, peer-to-peer system that gives access to a global audience of obtainers and providers (Beck et al., 2018). As such, it could re-empower peers who feel increasingly minored by qua-si-monopolistic giants such as platforms (e.g., Didi, Uber, Airbnb) and the GAFAM (Google, Amazon, Facebook, Apple and Microsoft) players offering intermittent collaborative solutions such as Facebook Marketplace or Amazon Prime, but also eBay and many others. Such attempts have already been made. For example, in 2017, engineers working on blockchain development for the Ethereum cryptocurrency founded Swarm City, a decentralized CE application which enables any individual to create his or her own brand at home without any intervention from a third party (i.e., a platform) (Beck et al., 2018). While several questions remain 
regarding the blockchain governance and whether it will remain decentralized and disintermediated as it is today (Campbell-Verduyn, 2018; Arsenault and Ertz, 2019). However, the key features of openness, decentralization and transparency of the blockchain surely make it a competitor platform that consistently struggles with legal, governance, industrial relations, and tax issues. Following the simple marketing rule, that any middleman that does not create value eventually becomes redundant and disappears (Breyer, 1934), it might be worth questioning to what extent the current platform model can sustain the competition of blockchain applications in the CE and SE overall.

\subsection{The disappearing user?}

In fine, users are the only one component who might not disappear. As stressed earlier, peers and businesses with deficit poles (demand) will always have needs to satisfy and will always exist. However, the recoil of either peer providers or platforms or both altogether signals a potential rearrangement of demand as well. Some obtainers are motivated by authenticity in collaborative exchange (Paulauskaite et al., 2017; Bucher et al., 2018) and may feel resentment when faced with a rising amount of business providers and offerings on supposedly "sharing schemes". The market could thus shrink to some extent but it is very unclear to what extent that shrinkage could be detrimental to platforms. However, since the critical mass remains an important driver of success in the collaborative economy (Tomasello, 2009), anything that makes that mass tinier should be of serious concern.

\section{Conclusion}

This paper sought to shed some light on the concept of the collaborative economy which was put in relation to the sharing economy as well as other nomologically-related concepts. Almost half a decade has passed after an initial conceptualization of CC and the collaborative economy as being characterized by the key criterion of the switchover opportunity, meaning that a resource circulation system is collaborative as long as it enables consumers to switch roles and become providers themselves (Ertz et al., 2016). That conceptualization remains valid today as well as the various channels (from purely online to purely offline), practices (from gift-giving to secondhand exchange) and forms of compensations (from free exchange to exchange at a cost) that were associated with CC (Ertz et al., 2019). However, in an attempt to better match the exponential research that has been conducted on the broader topic of the "sharing economy" and to most accurately reflect praxis, this study proposes that the sharing economy notion should be considered as an umbrella term that can be divided into three shades that often overlap.

First, pure collaboration involves genuine peer-to-peer exchange, either directly or facilitated by an intermediary, or completely mediated by an intermediary. Pure collaboration is the closest conceptualization of what was originally conceived of as "sharing economy services" as supplied by peers instead of businesses (Gyódi, 2019). Pure collaboration thus encompasses the subcomponents of direct collaboration, facilitated collaboration and mediated collaboration (which includes sourcing and trading collaboration). Second, intermittent collaboration refers to two-sided markets in which both pure collaboration (C2C and $\mathrm{C} 2 \mathrm{~B}$ ) and conventional collaboration (B2C and B2B) occurs. This form of collaboration is in fact the most prevalent one especially on platforms that adapt well to both consumer-to-consumer and business-to-consumer exchange. Finally, pseudo collaboration is mere conventional consumption as partly enacted in intermittent collaboration. While both pure collaboration and the collaborative component of intermittent collaboration form the collaborative economy, the sharing economy subsumes these three shades altogether.

The "platform" has become the increasingly prevalent embodiment of the sharing economy, both in theory and in practice. In fact, sharing economy equates increasingly with a web-mediated and platform-centric economy. This triadic configuration posits providers, platforms and users as the three founding poles. Yet, providers are less and less peers or even human, while platforms could be substituted for more open and transparent systems such as the blockchain, and thus recede from their central position. This also raises the question as to what will remain 
of collaborativity when peers will be significantly reduced to the point of becoming marginal, or worse, disappear. However, some niche markets could subsist in specific sectors and for premium or luxurious services. With the ebbing of both providers and platforms, the user base might mechanically decline. The maintenance of the critical mass will need to be checked closely for future sustainability.

\section{References}

AKBAR, Yusaf and TRACOGNA, Andrea. The sharing economy and the future of the hotel industry: Transaction cost theory and platform economics. In: International Journal of Hospitality Management. 2018. N. ${ }^{\circ}$ 71, pages 91-101. ISSN 0278-4319. https://doi.org/10.1016/j.jijhm.2017.12.004

ANDREASSEN, Tor, LERVIK-OLSEN, Line, SNYDER, Hannah, VAN RIEL, Allard, SWEENEY, Jillian and VAN VARENBERGH, Yves. Business model innovation and value-creation: The triadic way. In: Journal of Service Management. 2018. Vol. 29, n. ${ }^{\circ}$ 5, pages 883-906. ISSN 1757-5818. https://doi.org/10.1108/JOSM-052018-0125

ARNOULD, Eric and ROSE, Alexander. Mutuality: Critique and substitute for Belk's "sharing". In: Marketing Theory. 2016. Vol. 16, n. ${ }^{\circ}$ 1, pages 75-99. ISSN 1470-5931. https://doi.org/10.1177\%2F1470593115572669

BARDHI, Fleura and ECKHARDT, Giana. Access-Based Consumption: The Case of Car Sharing. In: Journal of Consumer Research. 2012. Vol. 39, n. ${ }^{\circ}$ 4, pages 881-898. ISSN 0093-5301. https://doi.org/10.1086/666376

BECK, Roman, MÜLLER-BLOCH, Christoph and KING, John Leslie. Governance in the Blockchain Economy: A Framework and Research Agenda. In: Journal of the Association for Information Systems. 2018. Vol. 19, n. ${ }^{\circ}$ 10, page 1. ISSN 1536-9323. https://doi.org/10.17705/1JAIS.00518

BELK, Russell. Sharing Versus Pseudo-Sharing in Web 2.0. In: The Anthropologist. 2014. Vol. 18, n. ${ }^{\circ}$ 1, pages 7-23. ISSN 0972-0073. https://doi.org/10.1080/09720073.2014.11891518

BELK, Russell, SHERRY, Jr, John and WALLENDORF, Melanie. A Naturalistic Inquiry Into Buyer and Seller Behavior at a Swap Meet. In: Journal of Consumer Research. 1988. Vol. 14, n. ${ }^{\circ}$, pages 449-470. ISSN 0093-5301. https://doi.org/10.1086/209128

BENOIT, Sabine, BAKER, Thomas, BOLTON, Ruth, GRUBER, Thorsten and KAN-DAMPULLY, Jay. A triadic framework for collaborative consumption (CC): Motives, activities and resources \& capabilities of actors. In: Journal of Business Research. 2017. Vol. 79, pages 219-227. ISSN 0148-2963. https://doi.org/10.1016/j. jbusres.2017.05.004

BERGADAÀ, Michelle. Le don d'objet: l'exploration de ses dimensions et des profils de donneurs aux œuvres de bienfaisance. In: Recherche et Applications en Marketing. 2006. Vol. 21, n. ${ }^{\circ}$ 1, pages 19-39. ISSN 0767-3701. https://doi.org/10.1177\%2F076737010602100104

BOTSMAN, Rachel and ROGERS, Roo. What's Mine Is Yours. The Rise of Collaborative Consumption. New York, NY: Penguin, 2010.

BREYER, Ralph. The Marketing Institution. New York, NY: McGraw-Hill, 1934.

BUCHER, Eliane, FIESELER, Christian, FLECK, Matthes and LUTZ Christoph. Authenticity and the sharing economy. In: Academy of Management Discoveries. 2018. Vol. 4, n. ${ }^{\circ} 3$, pages 294-313. ISSN (online) 2168-1007. https://doi.org/10.5465/amd.2016.0161

CAMPBELL-VERDUYN, Malcolm. Bitcoin and Beyond. London: Taylor \& Francis, 2017. ISBN 9780367264925.

$\mathrm{CHU}$, Hsunchi and LIAO, Shuling. Exploring Consumer Resale Behavior in C2C Online Auctions: Taxonomy and Influences on Consumer Decisions. In: Academy of Marketing Science Review. 2007. Vol. 2007, page 1. ISSN 1869-8182.

CIULLI, Francesca and KOLK, Ans. Incumbents and business model innovation for the sharing economy: Implications for sustainability. In: Journal of Cleaner Production. 2019. N. ${ }^{\circ} 214$, pages 995-1010. ISSN 0959-6526. https://doi.org/10.1016/j.jclepro.2018.12.295 
COLIN, Samantha. The Death of a Co-working Startup Highlights User Experience vs. Unit Economics [online] [accessed on: 19-08-2020]. Available at: https://www.propmodo.com/the-death-of-a-co-working-startuphighlights-user-experience-vs-unit-economics/

CORCIOLANI, Matteo and DALLI, Daniele. Gift-giving, sharing and commodity exchange at Bookcrossing.com: New insights from a qualitative analysis. In: Management Decision. 2014. Vol. 52, n. ${ }^{\circ} 4$, pages $755-776$. ISSN 0025-1747. https://doi.org/10.1108/MD-03-2012-0241

CURASI, Carolyn Folkman, PRICE, Linda and ARNOULD, Eric. How individuals' cherished possessions become families' inalienable wealth. In: Journal of Consumer Research. 2004. Vol. 31, n. ${ }^{\circ} 3$, pages 609-622. ISSN 0093-5301. https://psycnet.apa.org/doi/10.1086/425096

CURTIS, Steven Kane and LEHNER, Matthias. Defining the Sharing Economy for Sustainability. In: Sustainability. 2019. Vol. 11, n. ${ }^{\circ}$ 3, 567. ISSN 2071-1050. https://doi.org/10.3390/su11030567

CURTIS, Steven Kane and MONT, Oksana. Sharing economy business models for sustainability. In: Journal of Cleaner Production. N. ${ }^{\circ}$ 121519. ISSN 0959-6526. https://doi.org/10.1016/j.jclepro.2020.121519

DALLI, Daniele and CORCIOLANI, Matteo. Collective forms of resistance: The transformative power of moderate communities. In: International Journal of Market Research. 2008. Vol. 50, n. ${ }^{\circ} 6$, pages 757-775. ISSN 14707853. https://doi.org/10.2501\%2FS1470785308200195

DELLAERT, Benedict. The consumer production journey: Marketing to consumers as co-producers in the sharing economy. In: Journal of the Academy of Marketing Science. 2019. Vol. 47, n. ${ }^{\circ}$ 2, pages 238-254. ISSN 00920703. https://dx.doi.org/10.2139/ssrn.3102773

DREYER, Betine, LÜDEKE-FREUND, Florian, HAMANN, Ralph and FACCER, Kristy. Upsides and downsides of the sharing economy: Collaborative consumption business models' stakeholder value impacts and their relationship to context. In: Technological Forecasting and Social Change. 2017. N. ${ }^{\circ}$ 125, pages 87-104. ISSN 0040-1625. https://doi.org/10.1016/j.techfore.2017.03.036

ECKHARDT, Giana and BARDHI, Fleura. The Sharing Economy Isn't About Sharing at All. In: Harvard Business Review. 2015. Vol. 28, n. ${ }^{\circ}$ 1, pages 881-898. ISSN 0017-8012.

ECKHARDT, Giana, HOUSTON, Mark, JIANG, Baojun, LAMBERTON, Cait, RIND-FLEISCH, Aric and ZERVAS, Georgios. Marketing in the sharing economy. In: Journal of Marketing. 2019. Vol. 83, n. ${ }^{\circ}$, pages 5-27. ISSN 0022-2429. https://doi.org/10.1177\%2F0022242919861929

EISEND, Martin. Have We Progressed Marketing Knowledge? A Meta-Meta-Analysis of Effect Sizes in Marketing Research. In: Journal of Marketing. 2015. Vol. 79, n. ${ }^{\circ} 3$, pages 23-40. ISSN 0022-2429. https://doi.org/10.1509\%2Fjm.14.0288

ERTZ, Myriam and ARSENAULT, Joanie. Towards a technocratic governance system? In: International Journal of Innovation Studies. 2019. Vol. 3, n. ${ }^{\circ}$ 3, pages 71-72. ISSN 2096-2487. https://doi.org/10.1016/j.jijs.2019.11.001

ERTZ, Myriam and BOILY, Émilie. The rise of the digital economy: Thoughts on blockchain technology and cryptocurrencies for the collaborative economy. In: International Journal of Innovation Studies. 2019. Vol. 3, n. ${ }^{\circ} 4$, pages 84-93. ISSN 2096-2487. https://doi.org/10.1016/j.ijis.2019.12.002

ERTZ, Myriam and LEBLANC-PROULX, Sébastien. Sustainability in the collaborative economy: A bibliometric analysis reveals emerging interest. In: Journal of Cleaner Production. 2018. N. ${ }^{\circ} 196$, pages 1073-1085. ISSN 0959-6526. https://doi.org/10.1016/j.jclepro.2018.06.095

ERTZ, Myriam and SARIGÖLLÜ, Emine. Assessing the Potential of Sustainable Value Chains in the Collaborative Economy. In: Sustainability. 2019. Vol. 11, n. ${ }^{\circ}$ 2, 390. ISSN 2071-1050. https://doi.org/10.3390/su11020390

ERTZ, Myriam, DURIF, Fabien and ARCAND, Manon. Collaborative Consumption: Conceptual Snapshot at a Buzzword. In: Journal of Entrepreneurship Education. 2016. Vol. 19, n. ${ }^{\circ}$ 2, pages 1-23. ISSN 1528-2651. https://dx.doi.org/10.2139/ssrn.2799884

ERTZ, Myriam, DURIF, Fabien and ARCAND, Manon. A conceptual perspective on collaborative consumption. In: AMS Review. Vol. 9, n. ${ }^{\circ}$ 1/2, pages 27-41. ISSN 1869-814X. https://doi.org/10.1007/s13162-018-0121-3

ERTZ, Myriam, LEBLANC-PROULX, Sébastien, SARIGÖLLÜ, Emine and MORIN, Vincent. Made to break? A taxonomy of business models on product lifetime extension. In: Journal of Cleaner Production. 2019. N. ${ }^{\circ} 234$, pages 867-880. ISSN 0959-6526. https://doi.org/10.1016/j.jclepro.2019.06.264 
ERTZ, Myriam, LECOMPTE, Agnès. and DURIF, Fabien. Dual roles of consumers: Towards an insight into collaborative consumption motives. In: International Journal of Market Research. 2017. Vol. 59, n. ${ }^{\circ}$ 6, pages 725-748. ISSN 1470-7853. https://doi.org/10.2501\%2FIJMR-2017-040

FRENKEN, Koen and SCHOR, Juliet. Putting the sharing economy into perspective. In: FRENKEN, Koen and SCHOR, Juliet. A Research Agenda for Sustainable Consumption Governance. Cheltenham and Northampton, MA: Edward Elgar Publishing, 2019. ISBN 9781788117807.

GAIARDELLI, Paolo, RESTA, Barbara, MARTíNEZ, Veronica, PINTO, Roberto and ALBORES, Pavel. A classification model for product-service offerings. In: Journal of Cleaner Production. 2014. N. ${ }^{\circ} 66$, pages 507-519. ISSN 0959-6526. https://doi.org/10.1016/j.jclepro.2013.11.032

GANSKY, Lisa. The Mesh: Why the Future of Business Is Sharing. New York, NY: Penguin, 2010. ISBN 9781591844303.

GIESLER, Markus. Consumer Gift Systems. In: Journal of Consumer Research. 2006. Vol. 33, n. 2, pages 283290. ISSN 0093-5301. https://doi.org/10.1086/506309

GUIOT, Denis and ROUX, Dominique. A Second-hand Shoppers' Motivation Scale: Antecedents, Consequences, and Implications for Retailers. In: Journal of Retailing. 2010. Vol. 86, n. ${ }^{\circ} 4$, pages 355-371. ISSN 0022-4359. https://doi.org/10.1016/j.jretai.2010.08.002

GUYADER, Hugo and PISCICELLI, Laura. Business model diversification in the sharing economy: The case of GoMore. In: Journal of Cleaner Production. 2019. N. ${ }^{\circ} 215$, pages 1059-1069. ISSN 0959-6526. https://doi.org/10.1016/j.jclepro.2019.01.114

GYÓDI, Kristóf. Airbnb in European cities: Business as usual or true sharing economy? In: Journal of Cleaner Production. 2019. N. ${ }^{\circ}$ 221, pages 536-551. ISSN 0959-6526. https://doi.org/10.1016/j.jclepro.2019.02.221

HAMARI, Juho, SJÖKLINT, Mimmi and UKKONEN, Antti. The sharing economy: Why people participate in collaborative consumption. In: Journal of the Association for Information Science and Technology. 2016. Vol. 67, n. ${ }^{\circ}$ 9, pages 2047-2059. ISSN 2330-1635. https://doi.org/10.1002/asi.23552

HAWLITSCHEK, Florian, NOTHEISEN, Benedikt and TEUBNER, Timm. The limits of trust-free systems: A literature review on blockchain technology and trust in the sharing economy. In: Electronic Commerce Research and Applications. 2018. N. ${ }^{\circ}$ 29, pages 50-63. ISSN 1567-4223. https://doi.org/10.1016/j.elerap.2018.03.005

LAMBERTON, Cait and ROSE, Randall. When is Ours Better than Mine? A Framework for Understanding and Altering Participation in Commercial Sharing Systems. In: Journal of Marketing. 2012. Vol. 76, n. ${ }^{\circ}$ 4, pages 109-125. ISSN 0022-2429. https://dx.doi.org/10.2139/ssrn.1939289

LANGE, Nicki. Quick commerce (Q-commerce): The next generation of e-commerce [online] [accessed on 2804-2020]. Available at: https://www.nickilange.com/journal/2020/4/28/quick-commerce-the-next-generationof-e-commerce

MARTIN, Chris. The sharing economy: A pathway to sustainability or a nightmarish form of neoliberal capitalism? In: Ecological Economics. 2016. N. ${ }^{\circ} 121$, pages 149-159. ISSN 0921-8009. https://doi.org/10.1016/j. ecolecon.2015.11.027

MEELEN, Toon and FRENKEN, Koen. Stop Saying Uber Is Part of the Sharing Economy. In: Fast Company. 2015. N. ${ }^{\circ}$ 14. ISSN 1085-9241.

MOROZOV, Evgeny. The 'sharing economy' undermines workers' rights. In: Financial Times. 2013. N. ${ }^{\circ}$ 14. ISSN 0307-1766.

MUÑOZ, Pablo and COHEN, Boyd. A Compass for Navigating Sharing Economy Business Models. In: California ManagementReview.2018.Vol.61, n. ${ }^{\circ}$ 1, pages114-147.ISSN0008-1256. https://doi.org/10.1177\%2F0008125618795490

MURILLO, David, BUCKLAND, Heloise and VAL, Esther. When the sharing economy becomes neoliberalism on steroids: Unravelling the controversies. In: Technological Forecasting and Social Change. 2017. N. ${ }^{\circ}$ 125, pages 66-76. ISSN 0040-1625. https://doi.org/10.1016/j.techfore.2017.05.024

PAULAUSKAITE, Dominyka, POWELL, Raymond, COCA-STEFANIAK, J. Andres and MORRISON, Alastair. Living Like a Local: Authentic Tourism Experiences and the Sharing Economy. In: International Journal of Tourism Research. 2017. Vol. 19, n. ${ }^{\circ}$ 6, pages 619-628. ISSN 1099-2340. https://doi.org/10.1002/jtr.2134 
PERREN, Rebecca and KOZINETS, Robert. Lateral Exchange Markets: How Social Platforms Operate in a Networked Economy. In: Journal of Marketing. 2018. Vol. 82, n. ${ }^{\circ}$, pages 20-36. ISSN 0022-2429. https://doi.org/10.1509\%2Fjm.14.0250

PISCICELLI, Laura, LUDDEN, Geke and COOPER, Tim. What makes a sustainable business model successful? An empirical comparison of two peer-to-peer goods-sharing platforms. In: Journal of Cleaner Production. 2018. N. ${ }^{\circ}$ 172, pages 4580-4591. ISSN 0959-6526. https://doi.org/10.1016/j.jclepro.2017.08.170

PLEWNIA, Frederik and GUENTHER, Edeltraud. Mapping the sharing economy for sustainability research. In: Management Decision. 2018. Vol. 56, n. ${ }^{\circ}$ 3, pages 570-583. ISSN 0025-1747. https://doi.org/10.1108/MD-11-2016-0766

RYSMAN, Marc. The Economics of Two-Sided Markets. In: Journal of Economic Perspectives. 2009. Vol. 23, n. ${ }^{\circ}$ 3, pages 125-143. ISSN 0895-3309. https://doi.org/10.1257/jep.23.3.125

SCARABOTO, Daiane. Selling, Sharing, and Everything In Between: The Hybrid Economies of Collaborative Networks. In: Journal of Consumer Research. 2015. Vol. 42, n. ${ }^{\circ}$, pages 152-176. ISSN 0093-5301. https://doi.org/10.1093/jcr/ucv004

SCHOR, Juliet. Debating the sharing economy. In: Journal of Self-Governance and Management Economics. 2016. Vol. 4, n. ${ }^{\circ}$ 3, pages 7-22. ISSN 2329-4175. https://doi.org/10.22381/jsme4320161

SEYFANG, Gill and LONGHURST, Noel. Growing green money? Mapping community currencies for sustainable development. In: Ecological Economics. 2013. N. ${ }^{\circ}$ 86, pages 65-77. ISSN 0921-8009. https://doi.org/10.1016/j. ecolecon.2012.11.003

SHAW, Eric. The Marketing Institution by Ralph F. Breyer (1934). In: Journal of Historical Research in Marketing. 2014. Vol. 6, n. ${ }^{\circ}$ 3, pages 449-454. ISSN 1755-750X. https://doi.org/10.1108/JHRM-07-2013-0047

SLEE, Tom. New York: What's Yours Is Mine: Against the Sharing Economy. New York, NY: O/R Books, 2015. ISBN-13: 978-1944869373 ISBN-10: 1944869379.

TOMASELLO, Michael. Why We Cooperate. Cambridge, MA: MIT Press, 2009. ISBN: 9780262013598.

UBER ATG. We believe in the power of technology [online] [accessed on: 19-08-2019] Available at: https:// www.uber.com/us/en/atg/technology/

Recommended citation: ERTZ, Myriam. Collaborative consumption, a buzzword that has gone conceptual: Three shades of the sharing economy. Oikonomics [online]. November 2020, no. 14, pp. 1-14. ISSN: 2339-9546. DOI: https://doi.org/10.7238/o.n14.2011 




\section{Myriam Frtz}

\section{Université du Québec à Chicoutimi}

Myriam Ertz is Assistant Professor of Marketing at the department of economics and administrative sciences of Université du Québec à Chicoutimi. She is also the founder and the head of the LaboNFC (Laboratory of Research on New Forms of Consumption), is a research fellow at the Center of Research for the Development of Territories (CRDT), and is a member of the thematic interest group on marketing and sustainable development of the Association Française du Marketing (AFM). Her research interests include consumer choice modeling, sustainability, and the reconfiguration of commercial exchanges. Her research has already appeared in many toptier journal articles over the last four years (e.g., Resources, Conservation \& Recycling; Journal of Cleaner Production; Business Strategy \& the Environment; Journal of Environmental Management; Technological Forecasting \& Social Change; Journal of Business Research; Environment \& Behavior; Industrial Marketing Management; International Marketing Review). She has published 44 original research articles, seven book chapters, directed a collective book, published two monographs, written two case studies, contributed to multiple research reports, and communicated her research in 28 academic conferences. Her academic interests have been spurred and nourished by her practical experience in the private sector in Micro-MBA, Cape Town, FedEx Express EMEA, Belgium, and Altus Group, Canada.

The texts published in this journal are - unless otherwise indicated - covered by the Creative Commons Spain Attribution 4.0 International licence. Each article may thus be copied, distributed, communicated to the public and used as the basis for derivative works, provided that its author, the journal and its publishing institution are credited as specified by the author or journal. The full text of the licence can be consulted here: http://creativecommons.org/licenses/by/4.0/.

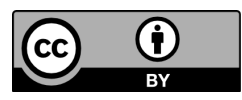

